\title{
The impact of large acquisitions on the share price and operating financial performance of acquiring companies listed on the JSE
}

\section{INTRODUCTION}

A KPMG survey in London found that $53 \%$ of mergers and acquisitions destroy shareholder value (Brewis, 2000). Andrade, Mitchell and Stafford (2001) state that two of the main objectives in corporate finance research are the measurement of value creation or destruction through mergers and acquisitions, and how this value creation or destruction is distributed between the acquiring company and the target company.

The aim of this research is to determine whether large acquisitions, concluded in 2001, 2002 or 2003 add value to acquiring companies listed on the JSE Limited ("the JSE"). The researchers examined the share price performance of the acquiring company around the acquisition announcement date and the impact on operating financial performance in the two years subsequent to the acquisition. These two most popular measures are used to provide a comprehensive analysis of the wealth effects of large acquisitions on a sample of South African acquiring companies. In contrast to the majority of international studies that only consider mergers and tender offers where both the acquirer and the target are publicly traded, this study considers all mergers and acquisitions, specifically including unlisted targets.

\section{LITERATURE REVIEW}

Andrade et al. (2001) state that economic theory suggests many reasons for mergers and acquisitions, for instance the pursuit of growth and success through synergies, economies of scale, greater efficiency in the management of assets and the removal of incompetent managers of the target firm. They further suggest that while some managers take advantage of the economic benefits of diversification opportunities, some mergers and acquisitions are undertaken for empire-building, or hubris.

The majority of published international and South African studies in this area focus on the short-term effects of acquisitions on the share price performance of the acquiring firm (pre-acquisition impact), whilst very few study the long-term effects (post-acquisition impact). Most of these use Average Cumulative Abnormal Returns (ACARs) as opposed to Average
Abnormal Returns (AARs) and the results of some of the most prominent studies of Average Cumulative Abnormal Returns (ACARs) are summarised in Table 1.

While several studies found significant positive ACARs, others found significant negative ACARs and still others found no statistical evidence of positive or negative ACARs. All these studies found small positive or negative returns compared to the consistent finding of statistically significant large positive returns to shareholders of target companies, as noted by Jarrel and Poulson (1989).

Table 2 summarises the findings of research that distinguished between acquiring companies' ACARs for cash-funded and share-funded acquisitions.

The general trend from Table 2 is that higher ACARs were noted for cash-funded acquisitions than for share-funded acquisitions, except for the finding by Fuller, Netter and Stegemoller (2002), who found that acquisitions of private companies return higher positive ACARs for share-funded acquisitions than for cashfunded acquisitions.

Another measure of post-acquisition performance to determine whether acquisitions create or destroy value is to compare the operating financial performance of the enlarged companies before and after acquisitions.

Healy, Palepu and Ruback (1992) studied 50 large mergers and acquisitions by U.S. industrial firms completed between 1979 and 1984 and found that operating financial performance (combined for the acquirer and the target), measured by way of cash flow return on assets, improves significantly as a result of a merger or acquisition relative to the industry, especially where focus is enhanced. They further found a positive correlation between the gains in share price returns (combined for the acquiring and the target companies) and the subsequent operating financial performance, concluding that announcement gains reflect future improvements in operating financial performance. 
The impact of large acquisitions on the share price and operating financial performance of acquiring companies listed on the JSE

Table 1: Summary of selected research findings of pre-acquisition Average Cumulative Abnormal Returns (ACARs) to acquiring firms

\begin{tabular}{|c|c|c|c|c|}
\hline Study & Period & Event Window (days) & Sample size & ACAR \\
\hline Jarrell and Poulson (1989) & $1963-1986$ & {$[-2,+1]$} & 461 & $0,70 \%$ *** \\
\hline Jarrell and Poulson (1989) & $1963-1986$ & {$[-10,+30]$} & 461 & $2,15 \%$ *** \\
\hline $\begin{array}{l}\text { Asquith, Bruner and Mullins } \\
\text { (1983) }\end{array}$ & $1963-1979$ & {$[-1,0]$} & 214 & $1,2 \% * * *$ \\
\hline Asquith et al. (1983) & $1963-1979$ & {$[-20,0]$} & 214 & $2,4 \%$ ** \\
\hline Loderer and Martin (1990) & $1966-1984$ & {$[-5,0]$} & 5172 & $0,69 \%$ *** \\
\hline Mulherin and Boone (2000) & $1990-1999$ & {$[-1,1]$} & 281 & $-0,37 \%$ \\
\hline Bradley, Desai and Kim (1988) & $1963-1984$ & [-5,5 after successful bid] & 236 & $0,97 \%$ *** \\
\hline Bradley et al. (1988) & $7 / 1963-6 / 1968$ & [-5,5 after successful bid] & 51 & $4,09 \% * * *$ \\
\hline Bradley et al. (1988) & $7 / 1968-12 / 1980$ & [-5,5 after successful bid] & 133 & $1,30 \%$ \\
\hline Bradley et al. (1988) & $1 / 1981-12 / 1984$ & {$[-5,5$ after successful bid] } & 52 & $-2,93 \%$ *** \\
\hline Fee and Thomas (2004) & $1980-1997$ & {$[-1,+1]$} & 554 & $-0,58 \%$ * \\
\hline Franks et al. (1991) & $1975-1984$ & {$[-5,+5]$} & 399 & $-1,02 \%$ \\
\hline Fuller et al. (2002) & $1990-2000$ & {$[-2,2]$} & 3135 & $1,77 \%$ *** \\
\hline Fuller et al. (2002) & $1990-2000$ & {$[-2,2]$} & $\begin{array}{l}456 \text { public } \\
\text { targets }\end{array}$ & $-1,00 \%$ ** \\
\hline Fuller et al. (2002) & $1990-2000$ & {$[-2,2]$} & $\begin{array}{l}2060 \text { private } \\
\text { targets }\end{array}$ & $2,08 \% * * *$ \\
\hline Mushidzhi and Ward (2004) & $3 / 1998-12 / 2002$ & {$[-10,+10]$} & 57 & $-0,55 \%$ \\
\hline Mushidzhi and Ward (2004) & $3 / 1998-12 / 2002$ & {$[-1,+1]$} & 57 & $0,31 \%$ \\
\hline
\end{tabular}

\footnotetext{
* - Statistically significant at the $10 \%$ level.

** - Statistically significant at the $5 \%$ level.

*** - Statistically significant at the $1 \%$ level.
}

Table 2: Summary of selected research findings of pre-acquisition Average Cumulative Abnormal Returns (ACARs) for share-funded and cash-funded acquisitions

\begin{tabular}{|c|c|c|c|c|c|c|c|c|}
\hline Study & Period & $\begin{array}{c}\text { Event } \\
\text { Window }\end{array}$ & $\begin{array}{l}\text { Sample size: } \\
\text { Full sample }\end{array}$ & $\begin{array}{l}\text { ACAR: } \\
\text { Full } \\
\text { sample }\end{array}$ & $\begin{array}{l}\text { Sample } \\
\text { size: } \\
\text { Share- } \\
\text { funded }\end{array}$ & $\begin{array}{l}\text { ACAR: } \\
\text { Share- } \\
\text { funded }\end{array}$ & $\begin{array}{c}\text { Sample } \\
\text { size: Cash- } \\
\text { funded }\end{array}$ & $\begin{array}{l}\text { ACAR: } \\
\text { Cash- } \\
\text { funded }\end{array}$ \\
\hline $\begin{array}{l}\text { Andrade et } \\
\text { al. (2001) }\end{array}$ & $\begin{array}{l}1973- \\
1998\end{array}$ & {$[-1,+1]$} & 3688 & $-0,7 \%$ & 2194 & $-1,5 \%$ ** & 1494 & $0,4 \%$ \\
\hline $\begin{array}{l}\text { Andrade et } \\
\text { al. (2001) }\end{array}$ & $\begin{array}{l}1973- \\
1998\end{array}$ & $\begin{array}{c}{[-} \\
20, \text { close] }\end{array}$ & 3688 & $-3,8 \%$ & 2194 & $-6,3 \%$ & 1494 & $-0,2 \%$ \\
\hline $\begin{array}{l}\text { Franks et } \\
\text { al. (1991) }\end{array}$ & $\begin{array}{l}1975- \\
1984\end{array}$ & {$[-5,+5]$} & 399 & $-1,02 \%$ & 128 & $-3,15 \%$ *** & 156 & $0,83 \%$ \\
\hline $\begin{array}{l}\text { Fuller et al. } \\
(2002)\end{array}$ & $\begin{array}{l}1990- \\
2000\end{array}$ & {$[-2,2]$} & 3135 & $1,77 \% * * *$ & 763 & $1,25 \%$ *** & 1530 & $1,78 \%$ *** \\
\hline $\begin{array}{l}\text { Fuller et al. } \\
(2002)\end{array}$ & $\begin{array}{l}1990- \\
2000\end{array}$ & {$[-2,2]$} & $\begin{array}{l}456 \text { public } \\
\text { targets }\end{array}$ & $-1 \%$ ** & $\begin{array}{l}218 \text { public } \\
\text { targets }\end{array}$ & $-1,86 \%$ ** & $\begin{array}{l}146 \text { public } \\
\text { targets }\end{array}$ & $0,34 \%$ \\
\hline $\begin{array}{l}\text { Fuller et al. } \\
(2002)\end{array}$ & $\begin{array}{l}1990- \\
2000\end{array}$ & {$[-2,2]$} & $\begin{array}{l}2060 \text { private } \\
\text { targets }\end{array}$ & $2,08 \% * * *$ & $\begin{array}{l}506 \text { private } \\
\text { targets }\end{array}$ & $2,43 \%$ *** & $\begin{array}{l}920 \text { Private } \\
\text { targets }\end{array}$ & $1,62 \%$ *** \\
\hline $\begin{array}{l}\text { Mushidzhi } \\
\text { and Ward } \\
\text { (2004) }\end{array}$ & $\begin{array}{l}3 / 1998- \\
12 / 2002\end{array}$ & {$[-10,+10]$} & 57 & $-0,55 \%$ & 33 & $-0,28 \%$ & 24 & $0,94 \%$ \\
\hline $\begin{array}{l}\text { Mushidzhi } \\
\text { and Ward } \\
(2004)\end{array}$ & $\begin{array}{l}3 / 1998- \\
12 / 2002\end{array}$ & {$[-1,+1]$} & 57 & $0,31 \%$ & 33 & $-0,24 \%$ & 24 & $1,07 \%$ \\
\hline
\end{tabular}


In a later study of the same sample and following the same research design, Healy and Palepu (1997) studied whether acquisitions generate additional cash flows beyond those required to cover the premium paid over the market value of the target at the time of acquisition. They find that this does not justify the premium. They interpret this finding that, on average, acquisitions are zero net present value investments. However, they note that there is significant crosssectional variation in abnormal operating financial performance (industry-adjusted cash flow return on assets) over a five-year period ranging from $-20 \%$ to $19 \%$.

The results of these and other studies of abnormal post-acquisition cash flow return on assets mentioned above are summarised in Table 3.

From Table 3, only Ghosh (2001) finds a significant post-acquisition improvement in cash flow return on assets, so it is not clear that this justifies the premium paid.

Although the empirical findings of the studies set out above remain relevant, mergers and tender offers of publicly listed companies occur less frequently in South Africa than the acquisition of unlisted companies by JSE-listed companies. This is an important matter, especially in light of the findings of Fuller et al. (2002), who studied 3135 transactions between 1990 and 2000 and found that acquiring shareholders gain when buying a private firm, irrespective of the method of payment (significantly positive AARs to acquiring companies of $2,08 \%$ were found in their study). They further noted that acquiring shareholders have insignificant AARs of $0,34 \%$ when purchasing public targets for cash, but significantly negative returns of $-1,86 \%$ when purchasing public targets for shares.

\section{RESEARCH HYPOTHESES}

The hypotheses were designed to study two measures described in the review of prior work on the impact of large acquisitions by JSE-listed companies, namely the effect on share price performance of the acquiring company around the acquisition announcement date and the impact on the combined operating financial performance of the acquiring company and the target company in the two years subsequent to the acquisition.

\section{Hypothesis 1:}

The null hypothesis states that the shareholders of acquiring companies do not earn positive or negative Average Cumulative Abnormal Returns (ACAR) around the announcement dates of large acquisitions. This hypothesis was also examined for cash versus share-financed acquisitions.

\section{Hypothesis 2:}

The null hypothesis states that the average industryadjusted operating cash flow return on tangible assets of the combined companies (acquiring company and

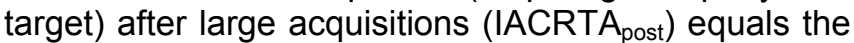
average Industry-Adjusted operating Cash Flow Return on Tangible Assets of the combined companies (acquiring company and target) prior to such acquisitions (IACRTA $A_{\text {pre }}$ ). This hypothesis was also tested for cash versus share-funded acquisitions.

Significance testing was at the $5 \%$ error level using two-tailed t-tests.

\section{RESEARCH METHODOLOGY}

The population of relevance was extracted from the database of mergers and acquisitions compiled by Ernst \& Young for their annual review of mergers and acquisitions in South Africa in 2000, 2001 and 2002. The market capitalisation of acquirers was calculated from information obtained from the McGregor's BFANet database. The population of relevance consisted of all transactions from the Ernst \& Young database that met the following criteria:

- the acquiring company was listed at the time of the acquisition, for at least one year prior and one year following the acquisition;

- the acquisition value was more than $20 \%$ of the market capitalisation of the acquirer;

- balance sheet and cash flow information of the target company was available in the circular to shareholders of the acquiring company;

- the acquiring company was not a cash shell before the acquisition;

- $\quad$ the acquiring company did not enter into any large acquisitions, disposals or any major corporate restructurings requiring shareholders' approval during one year before and one year after the large acquisition, to exclude the impact of confounding events.

The aim of this paper was to study the impact of acquisitions on both the share price performance and the operating financial performance of the same sample. Out of a total of 802 mergers and acquisitions during the three-year period, only 27 acquisitions met the criteria described. ${ }^{1}$ The reasons for the small sample size are the restrictions of the study to large acquisitions and to acquisitions during the three-year period from 2000 to 2002 .

\footnotetext{
${ }^{1}$ Details are available from the authors.
} 
The impact of large acquisitions on the share price and operating financial performance of acquiring companies listed on the JSE

Table 3: Summary of selected post-acquisition abnormal cash flow return on assets

\begin{tabular}{lcccl}
\hline \multicolumn{1}{c}{ Study } & Sample size & Period & $\begin{array}{c}\text { Performance } \\
\text { period (years) }\end{array}$ & Median abnormal return \\
\hline Healy et al. (1992) & 50 & $1979-1984$ & {$[-5,-1]$} & $\begin{array}{l}0,3 \% \text { (assuming no premium } \\
\text { paid) } \\
2,8 \% \%^{* * *} \text { (assuming no } \\
\text { premium paid) }\end{array}$ \\
Healy et al. (1992) & 50 & $1979-1984$ & {$[1,5]$} & $\begin{array}{l}0,5 \% \text { (accounting for actual } \\
\text { premium paid) }\end{array}$ \\
Healy and Palepu (1997) & 50 & $1979-1984$ & {$[-5,-1]$} & $\begin{array}{l}2,1 \% \text { (accounting for actual } \\
\text { premium paid) } \\
2,81 \% \%^{* * *}\end{array}$ \\
Healy and Palepu (1997) & 50 & $1979-1984$ & {$[1,5]$} & $3,06 \% \%^{* * *}$ \\
\hline
\end{tabular}

*** - Significantly different from zero at the $1 \%$ level.

The study of post-acquisition operating financial performance is the most important contribution of this paper, because some South African studies have considered the pre-acquisition impacts of mergers and acquisitions on share price performance, but no published South African studies were noted that considered post-acquisition operating financial performance. The focus on large acquisitions was a necessary prerequisite to study post-acquisition operating financial performance because the preacquisition historical operating financial performance of unlisted target firms is only required to be publicly disclosed in terms of the Listings Requirements of the JSE (by way of a circular to the acquiring company's shareholders) if the acquisition is a Category 1 or Category 2 transaction, as defined in the Listings Requirements of the JSE. A Category 2 acquisition is where the value of the target is between $20 \%$ and $30 \%$ of the market capitalisation of the JSE-listed acquiring company, and a Category 1 acquisition is where the value of the target is more than $30 \%$ of the market capitalisation of the JSE-listed acquiring firm. Accordingly, the financial information required to study operating financial performance is only publicly available in the case of large acquisitions.

The format and scope of the Ernst \& Young mergers and acquisitions database changed in 1999 and, consequently, acquisitions during or prior to 1999 could not be considered for selection. Acquisitions after 2002 were not considered for selection because two years' post-acquisition information was not available at the time of the study.

Whilst the small sample size is concerning, Brown and Warner (1985, p. 25) note that "standard parametric tests for significance of the mean excess return are well-specified. In samples of only 5 securities, and even when days are clustered, the tests typically have the appropriate probability of Type I error." It should be noted that, because the sample was selected judgmentally (i.e. all mergers and acquisitions that met the abovementioned criteria) and not randomly, there are some limitations on the statistical inferences made.
Transactions were eliminated when their securities traded on the JSE for fewer than 10 days during the 21 days $[-10,+10]$ around the announcement date; accordingly a further seven were excluded for the study of abnormal share price performance. Daily share prices for the selections were extracted from the McGregor's BFANet database.

For each acquisition the operating financial performance of the acquiring company before the acquisition and the operating financial performance of the enlarged company (combined acquiring company and target company) after the acquisition was obtained from the McGregor's BFANet database. Where the required information was not available from the McGregor's BFANet database, it was obtained from the published annual reports or pre-listing statement of the acquiring company. For each selection, the operating financial performance of the target company before the acquisition was obtained from the circular to shareholders of the acquiring company. In instances where confounding events occurred within the second year before and/or after the acquisition, such second year was excluded from the data analysis. Following Healy et al. (1992), Year 0, the financial year in which the effective date of the transaction occurred, was excluded from data analysis.

\subsection{Impact on pre-acquisition share price returns}

The first step in the data analysis was to determine the expected return. A Control Portfolio Model was used to determine the expected returns following the methodology of Mordant and Muller (2003). All companies listed on the JSE were classified into one of eight control portfolios based on combinations of the price-to-book value ratio, the company size and the resource effect.

All shares listed on the JSE during a particular month were categorised into one of these eight control portfolios. Once the eight control portfolios were constructed, the daily share prices for each share in each portfolio were obtained and the daily return 
estimated. The control portfolios were rebalanced at the beginning of each month to ensure that each portfolio continued to be an accurate measurement of the equally weighted share price returns of that control portfolio as a result of changes in price-to-book value ratios, market capitalisations, new listing and delistings.

Following Mordant and Muller (2003), the daily share returns for each acquisition were regressed for the 378 trading days preceding the acquisition announcement date against the daily returns of each of the eight control portfolios to obtain a regression equation (Equation 1) for each event.

$$
\begin{aligned}
E\left(R_{i t}\right)= & \alpha_{i, t}+\beta_{i, 1} N G L_{t}+\beta_{i, 2} N G S_{t}+\beta_{i, 3} N V L_{t}+ \\
& \beta_{i, 4} N V S_{t}+\beta_{i, 5} R L_{t}+\beta_{i, 6} R S_{t}+\beta_{i, 7} R V L_{t}+ \\
& \beta_{i, 8} R V S_{t}+\varepsilon_{i t}
\end{aligned}
$$

where:

$$
\begin{array}{ll}
E\left(R_{i t}\right)= & \text { the expected return on security } i \text { on } \\
& \text { day } t ; \\
= & \text { the alpha intercept term of security } i \\
& \text { on day } t ; \\
\alpha_{i, t} & =\begin{array}{l}
\text { the beta coefficients on each control } \\
\text { portfolio return; and }
\end{array}
\end{array}
$$

$N G L_{t} \ldots R V S_{t}=$ the log-function share price returns on each of the eight control portfolios on day $t$, where $\mathrm{N}$ means nonresource company, $R$ means resource company, $\mathrm{G}$ means growth company (high price-to-book value ratio), $\mathrm{V}$ means value company (low price-to-book value ratio), $L$ means large company (in JSE top 100) and $S$ means small company; e.g. NGL means a non-resource, growth, large company.

After determining the intercept and the beta coefficients of the regression equation for each aquisition, the expected return for each event for each day in the event window was calculated using the average return for each of the eight control portfolios over the event window. Four event windows were studied, namely the 21-day window $[-10,+10]$, the 11day window $[-5,+5]$, the 5 -day window $[-2,+2]$ and the 3 -day window $[-1,+1]$ around the announcement date. Abnormal returns for each day of each event were then calculated.

The daily Abnormal Returns (ARs), were accumulated to obtain Cumulative Abnormal Returns (CAR) and Average Cumulative Abnormal Returns (ACAR's) for each event window.
Two-tailed t-tests were performed at the $5 \%$ error level to determine whether the ACAR differed statistically significantly from zero (Hypothesis 1). Secondly, the ACAR for share-funded acquisitions and the ACAR for cash-funded acquisitions were compared for each event window.

\subsection{Impact on post-acquisition operating financial performance (cash flow return on assets)}

The abnormal cash flow return on assets was determined by comparing the cash flow return on assets for each acquisition with the same period's median cash flow return on assets of the relevant acquiring company's industry sector (but excluding the cash flow return on assets of the relevant acquiring company), following Healy et al. (1992). Ghosh's (2001) approach of matching the sample selection to an industry peer with comparable pre-acquisition cash flow return on assets and comparable size as the sample selection was not followed because several of the selections did not have industry-peers that met the conditions set by Ghosh (2001). Each acquisition was matched with its narrow industry sub-sector on the JSE. In instances where the narrow industry subsector had too few constituent companies, such sample selection was matched with its wider sector classification.

Equation 2 was used to determine the abnormal cash flow return on assets for the years before the merger or acquisition.

$\mathrm{ACRA}_{a+t, y}=\underset{\operatorname{ICFA}_{y}}{\left(\left(C F_{a, y}+C F_{t, y}\right) /\left(A_{a, y}+A_{t, y}\right)\right)-}$

where:

$\mathrm{ACRA}_{a+t, y}=$ the abnormal cash flow return on assets for the acquiring company a, and the target company $t$, for year $y$ (before the acquisition), combined on a pro forma basis;

$\mathrm{CF}_{\mathrm{a}, \mathrm{y}} \quad=$ the operating cash flow for the acquiring company a for year $y$ (before the acquisition);

$\mathrm{CF}_{\mathrm{t}, \mathrm{y}} \quad=$ the operating cash flow for the target company $t$ for year $y$ (before the acquisition);

$\mathrm{A}_{a, y} \quad=$ the assets of the acquiring company $a$, at the end of year $y$ (before the acquisition);

$\mathrm{A}_{t, \mathrm{y}} \quad=$ the assets of the target company $\mathrm{t}$, at the end of year $y$ (before the acquisition); and 


$\begin{aligned} \text { ICFA }_{y}= & \text { the median industry cash flow return } \\ & \text { on assets for year } y \text { (before the } \\ & \text { acquisition). }\end{aligned}$

Equation 3 was used to determine the abnormal cash flow return on assets for the years after the merger or acquisition.

$$
\mathrm{ACRA}_{c, y}=\left(\mathrm{CF}_{c, y} / \mathrm{A}_{c, y}\right)-\mathrm{ICFA}_{\mathrm{y}}
$$

where:

$$
\begin{aligned}
\mathrm{ACRA}_{c, y}= & \text { the abnormal cash flow for the } \\
& \text { combined entity } \mathrm{c} \text {, for year } \mathrm{y} \text { (after } \\
& \text { the acquisition); } \\
= & \text { the operating cash flow for the } \\
& \text { combined company } \mathrm{c}, \text { for year } \mathrm{y} \\
& \text { (after the acquisition); } \\
\mathrm{CF}_{c, y}= & \text { the assets of the combined company } \\
& \mathrm{c} \text {, at the end of year } \mathrm{y} \text { (after the } \\
& \text { acquisition); and } \\
\mathrm{A}_{c, y} \quad & \text { the median industry cash flow return } \\
& \text { on assets for year } \mathrm{y} \text { (after the } \\
& \text { acquisition). }
\end{aligned}
$$

Two sets of analyses were performed, namely (1) the Industry-Adjusted Cash Flow Return on Tangible Assets ("IACRTA"), ignoring the acquisition premium (goodwill) paid, which approach can be approximated to the research design of Healy et al. (1992); and (2) the Industry-Adjusted Cash Flow Return on All Assets ("IACRAA"), specifically including the acquisition premium (goodwill) paid, which approach can be approximated to the research design of Healy and Palepu (1997). Since the results were similar, only the first approach is reported.

The IACRTA for each acquisition was determined for each of the two years prior and the two years post the acquisition. The average and median IACRTA for the acquisition were then calculated for each year. Where the cash flow return on asset information was not available for a particular year (e.g. the company was not listed on the JSE at the time) or where a confounding event occurred in a particular year, that selection was excluded from the calculation. Year 0 , the year of the effective date of the acquisition, was excluded for the reasons set out above, following
Healy et al. (1992), Healy and Palepu (1997) and Ghosh (2001).

\section{RESULTS}

\subsection{Impact on pre-acquisition share price returns}

Table 4 contains the ACAR and the t-statistic for the four event windows for the full sample and for sharefunded and cash-funded acquisitions.

Figure 1 depicts the ACARs for the full and split samples over the 21 -day event window $[-10,+10]$.

Table 5 sets out the IACRTA for each of the two years before and after the acquisitions in respect of the 27 selected acquisitions during the three-year period from 2000 to 2002. The mean IACRTA was calculated as the mean cash flow return on tangible assets less the industry median cash flow return on tangible assets, following Healy et al. (1992). The t-statistic on the mean was calculated applying the standard t-test formula, namely the mean divided by the crosssectional standard error. The median IACRTA was calculated as the median cash flow return on tangible assets less the industry median cash flow return on tangible assets, again following Healy et al. (1992). The t-statistic on the median was calculated by dividing the median by the cross-sectional standard error. While t-statistics on the median are unusual, this methodology was applied by Healy et al. (1992) due to the high variation in IACRTA, as evident from the standard deviations in Table 5.

\section{DISCUSSION OF RESULTS}

Table 4 indicates that, in the case of the full sample considered in this study, no statistically significant ACARs were observed for any of the event windows.

Although this study found a positive ACAR of $4,35 \%$ and negative ACAR of $-0,02 \%$ over the 21-day [$10,+10]$ and the 3-day $[-1,+1]$ event windows respectively, compared to findings of Mushidzhi and Ward (2004) of negative ACAR of $-0,55 \%$ and positive ACAR of $0,31 \%$ over the same periods, none of the ACARs in either these two studies were statistically significant in the case of the full sample. 
The impact of large acquisitions on the share price and operating financial performance of acquiring companies listed on the JSE

Table 4: Average Cumulative Abnormal Return (ACAR)

\begin{tabular}{|c|c|c|c|c|c|c|}
\hline & \multicolumn{2}{|c|}{$\begin{array}{l}\text { Full sample } \\
(n=27)\end{array}$} & \multicolumn{2}{|c|}{$\begin{array}{l}\text { Share-funded acquisitions } \\
\qquad(n=13)\end{array}$} & \multicolumn{2}{|c|}{$\begin{array}{l}\text { Cash-funded acquisitions } \\
\qquad(n=10)\end{array}$} \\
\hline & ACAR & t-stat & ACAR & t-stat & ACAR & t-stat \\
\hline $\begin{array}{l}{[-10,+10]} \\
{[-5,+5]} \\
{[-2,+2]} \\
{[-1,+1]}\end{array}$ & $\begin{array}{r}4,35 \% \\
3,79 \% \\
0,98 \% \\
-0,02 \% \\
\end{array}$ & $\begin{array}{l}1,223 \\
1,535 \\
0,574 \\
0,019 \\
\end{array}$ & $\begin{array}{c}1,89 \% \\
2,76 \% \\
-1,89 \% \text { * } \\
-1,92 \%\end{array}$ & $\begin{array}{l}0,531 \\
1,547 \\
2,030 \\
1,271\end{array}$ & $\begin{array}{r}11,50 \% \\
7,43 \% \\
5,92 \% \\
3,10 \%\end{array}$ & $\begin{array}{l}1,429 \\
1,168 \\
1,418 \\
1,509\end{array}$ \\
\hline
\end{tabular}

Table 5: Pre- and post-acquisition Industry-Adjusted Cash Flow Return on Tangible Assets (IACRTA)

\begin{tabular}{|c|c|c|c|c|c|c|c|}
\hline $\begin{array}{l}\text { Year relative to } \\
\text { acquisition }\end{array}$ & $\begin{array}{c}\text { Number of } \\
\text { observations }\end{array}$ & $\begin{array}{l}\text { Mean } \\
\text { IACRTA }\end{array}$ & $\begin{array}{c}\% \\
\text { positive }\end{array}$ & $\begin{array}{l}\text { Standard } \\
\text { Deviation }\end{array}$ & $\begin{array}{l}\text { t-stat for } \\
\text { mean } \\
\text { IACRTA }\end{array}$ & $\begin{array}{l}\text { Median } \\
\text { IACRTA }\end{array}$ & $\begin{array}{l}\text { t-stat for } \\
\text { median } \\
\text { IACRTA }\end{array}$ \\
\hline \multicolumn{8}{|l|}{ Full sample } \\
\hline-2 & 23 & $3,81 \%$ * & $65,22 \%$ & $10,42 \%$ & 1,754 & $4,59 \%$ ** & 2,113 \\
\hline-1 & 27 & $-0,98 \%$ & $55,56 \%$ & $16,99 \%$ & 0,300 & $1,10 \%$ & 0,336 \\
\hline+1 & 27 & $5,17 \%$ & $59,26 \%$ & $59,26 \%$ & 0,454 & $2,10 \%$ & 0,184 \\
\hline+2 & 23 & $2,96 \%$ & $52,17 \%$ & $36,35 \%$ & 0,391 & $0,53 \%$ & 0,070 \\
\hline$-2 \&-1$ & 27 & $0,98 \%$ & $55,56 \%$ & $12,15 \%$ & 0,419 & $1,57 \%$ & 0,672 \\
\hline$+1 \&+2$ & 27 & $3,01 \%$ & $52,96 \%$ & $45,90 \%$ & 0,341 & $1,34 \%$ & 0,151 \\
\hline \multicolumn{8}{|l|}{$\begin{array}{l}\text { Share-funded } \\
\text { acquisitions }\end{array}$} \\
\hline-2 & 11 & $1,82 \%$ & $54,55 \%$ & $10,44 \%$ & 0,577 & $4,14 \%$ & 1,314 \\
\hline-1 & 13 & $1,57 \%$ & $46,15 \%$ & $11,89 \%$ & 0,475 & $-1,52 \%$ & 0,460 \\
\hline+1 & 13 & $21,35 \%$ & $53,85 \%$ & $75,40 \%$ & 1,021 & $2,10 \%$ & 0,100 \\
\hline+2 & 11 & $4,78 \%$ & $45,45 \%$ & $53,65 \%$ & 0,295 & $-0,17 \%$ & 0,010 \\
\hline$-2 \&-1$ & 13 & $0,97 \%$ & $38,46 \%$ & $10,83 \%$ & 0,323 & $-1,79 \%$ & 0,594 \\
\hline$+1 \&+2$ & 13 & $13,28 \%$ & $61,54 \%$ & $61,11 \%$ & 0,784 & $1,63 \%$ & 0,096 \\
\hline \multicolumn{8}{|l|}{$\begin{array}{l}\text { Cash-funded } \\
\text { acquisitions }\end{array}$} \\
\hline-2 & 8 & $4,42 \%$ & $62,50 \%$ & $11,84 \%$ & 1,056 & $3,27 \%$ & 0,781 \\
\hline-1 & 10 & $-7,34 \%$ & $50,50 \%$ & $23,16 \%$ & 1,002 & $-0,80 \%$ & 0,109 \\
\hline+1 & 10 & $-16,64 \%$ & $50,50 \%$ & $40,57 \%$ & 1,297 & $-0,59 \%$ & 0,046 \\
\hline+2 & 9 & $0,54 \%$ & $44,44 \%$ & $4,75 \%$ & 0,342 & $-0,10 \%$ & 0,060 \\
\hline$-2 \&-1$ & 10 & $-1,56 \%$ & $60,00 \%$ & $14,84 \%$ & 0,332 & $1,45 \%$ & 0,309 \\
\hline$+1 \&+2$ & 10 & $-11,41 \%$ & $50,00 \%$ & $26,77 \%$ & 1,347 & $-0,38 \%$ & 0,044 \\
\hline * & Ct & hificant at $t$ & $\%$ error le & & & & \\
\hline
\end{tabular}

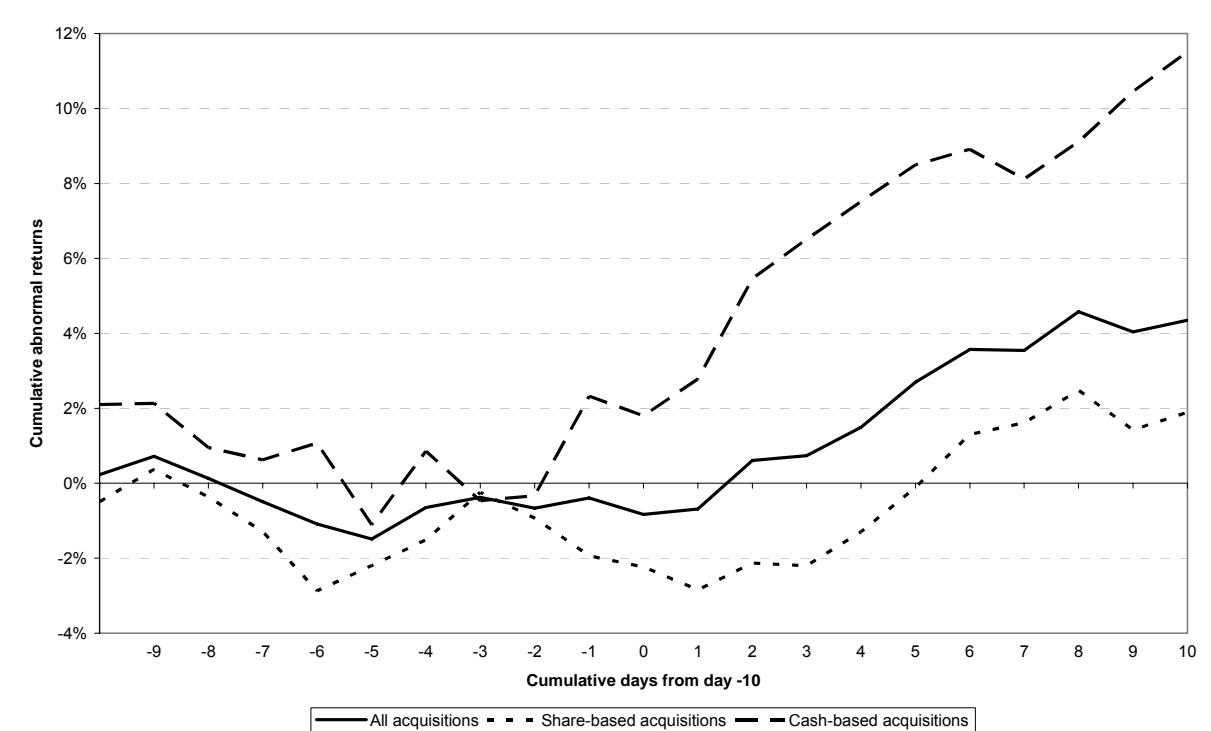

Figure 1: Average cumulative abnormal returns for full and split samples over 21-day event window 
This finding of lower ACARs for share-funded acquisitions versus cash-funded acquisitions, although not statistically significant, is consistent with that of most international research. Andrade et al. (2001), Franks, Harris and Titman (1991) and Fuller et al. (2002), for example, found statistical evidence of value destruction (negative ACARs) over very short event windows in the case of share-funded acquisitions. This finding is also consistent with the signalling hypothesis, namely that share-funded acquisitions convey negative information that the shares of the acquiring company are overvalued, while cash-funded transactions convey positive information that the shares of the acquiring company are undervalued.

This outperformance of cash-funded acquisitions is evident in Figure 1, but not statistically significant. ACARs were initially negative in the period preceding the announcement date, but turned positive in the days following the announcement date. This was consistent with Mushidzhi and Ward (2004), but in contrast to the findings of Andrade et al. (2001), Franks et al. (1991) and Fuller et al. (2002) who found statistically significant value destruction (negative ACARs) over very short event windows in the case of cash-funded acquisitions.

Table 5 indicates that, for the full sample, no statistically significant IACRTAs were observed at the $5 \%$ level for any of the two years before or after large acquisitions, except for the significant positive IACRTA for the full sample in the second year before the acquisition. Table 5 also indicates that no statistically significant difference was observed between the IACRTA of share-funded and cash-funded acquisitions.

It should be noted that, in terms of both mean and median IACRTA, the companies in the sample still outperformed their industry peers in the postacquisition period for the full sample and for sharefunded acquisitions (but not for cash-funded acquisitions). This outperformance was lower than in the pre-acquisition period, although none of these findings are statistically reliable.

Table 6 summarises the findings of this study and shows that the results correspond approximately with the study by Healy et al. (1992) which considered the cash flow return on assets at market value, but excluding the acquisition premium. Healy et al. (1992), assuming no premium is paid, concluded that median industry-adjusted operating financial performance improved from a statistically insignificant $0,3 \%$ before the event to a statistically significant $2,8 \%$ after such event.
The finding of Ghosh (2001) that share-funded acquisitions are particularly expensive as evidenced by a decline in performance following such acquisition was not found in this study. Although operating financial performance did decline after the acquisition, this finding was statistically no different from that of cash-funded acquisitions. The only finding of statistical significance in operating financial performance in this study was that of positive median IACRTA of $4,59 \%$ for the full sample in the second year before the acquisition. This finding is consistent with the statement by Ghosh (2001) that firms most often conclude mergers and acquisitions after a period of superior performance. Similar to Healy and Palepu (1997), this study found substantial cross-sectional variation in abnormal operating financial performance as evident from the large standard deviations.

The overall conclusion of the study of operating financial performance before and after large acquisitions is that large mergers and acquisitions, on average, do not result in any improvement or deterioration in the operating financial performance of the enlarged entity. This finding is consistent with that of Healy and Palepu (1997) and Ghosh (2001), namely that mergers and acquisitions are, on average, zero net present value investments.

\section{CONCLUSION}

This research found that shareholders of acquiring companies do not earn statistically significant positive or negative Abnormal Returns around the announcement date and no statistically significant ACARs were observed for any of the event windows considered in this study.

As with most international studies, this study found that ACARs of cash-funded acquisitions were positive, although statistically insignificant, whilst those for share-funded acquisitions were not only consistently lower, but were also observed as negative over the shorter 5-day and 3-day event windows.

Although not statistically significant, a $1,90 \%$ deterioration in the median Industry-Adjusted Cash Flow Return on Tangible Assets (IACRTA) was found between the pre-acquisition period to the postacquisition period for the full sample, while a $0,81 \%$ deterioration for share-funded acquisitions and a $3,57 \%$ deterioration for cash-funded acquisitions were noted. 

on the JSE

Table 6: Comparison of results of abnormal pre- and post-acquisition operating financial performance with international studies

\begin{tabular}{|c|c|c|c|c|}
\hline Study & $\begin{array}{l}\text { Sample } \\
\text { size }\end{array}$ & Period & $\begin{array}{l}\text { Performance } \\
\text { period (years) }\end{array}$ & Abnormal return \\
\hline Healy et al. (1992) & 50 & $1979-1984$ & {$[-5,-1]$} & $\begin{array}{l}0,3 \% \text { (assuming no premium paid) similar to } \\
\text { IACRTA }\end{array}$ \\
\hline Healy et al. (1992) & 50 & $1979-1984$ & {$[+1,+5]$} & $\begin{array}{l}2,8 \%^{* * *} \text { (assuming no premium paid) similar } \\
\text { to IACRTA }\end{array}$ \\
\hline Healy and Palepu (1997) & 50 & $1979-1984$ & {$[-5,-1]$} & $\begin{array}{l}0,5 \% \text { (accounting for actual premium paid) } \\
\text { similar to IACRAA }\end{array}$ \\
\hline Healy and Palepu (1997) & 50 & $1979-1984$ & {$[+1,+5]$} & $\begin{array}{l}2,1 \% \text { (accounting for actual premium paid) } \\
\text { similar to IACRAA }\end{array}$ \\
\hline Ghosh (2001) & 315 & $1981-1995$ & {$[-3,-1]$} & $2,81 \%$ *** \\
\hline Ghosh (2001) & 315 & $1981-1995$ & {$[+1,+3]$} & $3,06 \%{ }^{* * *}$ \\
\hline This paper & 27 & $2000-2002$ & {$[-2,-1]$} & $\begin{array}{l}1,57 \% \text { IACRTA (excluding intangible } \\
\text { assets) }\end{array}$ \\
\hline This paper & 27 & $2000-2002$ & {$[+1,+2]$} & $\begin{array}{l}1,34 \% \text { IACRTA (excluding intangible } \\
\text { assets) }\end{array}$ \\
\hline This paper & 27 & $2000-2002$ & {$[-2,-1]$} & $\begin{array}{l}1,42 \% \text { IACRAA (including intangible } \\
\text { assets) }\end{array}$ \\
\hline This paper & 27 & $2000-2002$ & {$[+1,+2]$} & $\begin{array}{l}0,91 \% \text { IACRAA (including intangible } \\
\text { assets) }\end{array}$ \\
\hline
\end{tabular}

** - Significantly different from zero at the $1 \%$ level, using a two-tailed test

Based on the findings of insignificant ACARs around the announcement date and insignificant changes in industry-adjusted operating financial performance, it is concluded that large acquisitions are, on average, zero net present value investments for acquiring companies and their shareholders. This conclusion questions whether the reasons given for mergers and acquisitions, such as pursuit of growth and value creation through synergies, economies of scale, greater efficiency in the management of assets, as noted by Andrade et al. (2001) are valid. The study supports the statement of Roll (1986, p.197) that "we still do not understand the motives behind mergers and tender offers or whether they bring an increase in market value".

The most substantial contribution of this study is that it is one of the few, if not the only, South African study that considered the impact of large acquisitions on the operating financial performance of acquiring companies. This is, however, a field that deserves extensive further research over a longer time period. The period of post-acquisition operating financial performance should also be extended to beyond the two years studied in this research, since it is possible that synergistic benefits from acquisitions are only achieved a number of years after the acquisition. A study of operating financial performance based on market values, where both acquirer and target were listed prior to the acquisition, is also suggested as this may provide a different conclusion.

\section{REFERENCES}

Andrade G, Mitchell M and Stafford E. 2001. New evidence and perspectives on mergers. Journal of Economic Perspectives, 15: 103-120.

Asquith P, Bruner RF and Mullins DW. 1983. The gains to bidding firms from merger. Journal of Financial Economics, 11: 121-139.

Bradley M, Desai A and Kim EH. 1988. Synergistic gains from corporate acquisition and their division between the stockholder of target and acquiring firms. Journal of Financial Economics, 21: 3-40.

Brewis J. 2000. Most M\&A deals fail to add value. Corporate Finance, 182: 8.

Brown SJ and Warner JB. 1985. Using daily stock returns. Journal of Financial Economics, 14: 3-31.

Fee CE and Thomas S. 2004. Sources of gains in horizontal mergers: Evidence from customer, supplier, 
and rival firms. Journal of Financial Economics, 74: 423-460.

Franks J, Harris R and Titman S. 1991. The postmerger share-price performance of acquiring firms. Journal of Financial Economics, 29(1): 81-96.

Fuller K, Netter J and Stegemoller M. 2002. What do returns of acquiring firms tell us? Evidence from firms that make many acquisitions. The Journal of Finance, 57(4): 1763-1793.

Ghosh A. 2001. Does operating performance really improve following corporate acquisitions? Journal of Corporate Finance, 7: 151-178.

Healy PM and Palepu KG 1997. Which takeovers are profitable? Strategic or financial? Sloan Management Review, 38(4): 45-57.

Healy PM, Palepu KG and Ruback RS. 1992. Does corporate performance improve after mergers? Journal of Financial Economics, 31: 135-175.

Jarrell GA and Poulson AB. 1989. The returns to acquiring firms in tender offers: Evidence from three decades. Financial Management, 18(3): 12-19.

Loderer C and Martin K. 1990. Corporate acquisitions by listed firms: The experience of a comprehensive sample. Financial Management, 19(4): 17-33.

Mordant $\mathrm{N}$ and Muller C. 2003. Profitability of directors' share dealings on the JSE. Investment Analysts Journal, 57: 17-21.

Mulherin JH and Boone AL. 2000. Comparing acquisitions and divestures. Journal of Corporate Finance, 6: 117-139.

Mushidzhi TB and Ward MJD. 2004. Abnormal returns for cash vs share funded acquisitions. Investment Analysts Journal, 60: 17-31.

Roll R. 1986. The hubris hypothesis of corporate takeovers. Journal of Business, 59(2): 197-216.

Strategic Direction. 2004. When mergers mean acquisition of headaches. Strategic Direction, 20(4): 16-19. 